\title{
Penggunaan Fitobiotik Nanoenkapsulasi Minyak Buah Merah untuk Meningkatkan Persentase Kerkas dan Meat Bone Ratio Ayam Kampung Super di Kabupaten Manokwari
}

\author{
Saputri Anjar Wati ${ }^{1}$, Nani Zurahmah ${ }^{1}$, Bangkit Lutfiaji Syaifullah ${ }^{1 *}$ \\ ${ }^{1}$ Progam Studi Penyuluhan Peternakan dan Kesejahteraan Hewan, Politeknik Pembangunan \\ Pertanian Manokwari \\ *Corresponding author: bangkitlutfiaji@gmail.com
}

\begin{abstract}
Abstrak
Penelitian ini bertujuan untuk mengetahui pengaruh pemberian fitobiotik minyak buah merah terhadap persentase karkas dan meat bone ratio ayam kampung super yang diaplikasikan dalam air minum sabagai bahan untuk meningkatkan produktivitas ayam kampung super. Penelitian ini menggunakan rancangan acak legkap pola searah dengan 5 perlakuan dan 4 ulangan, setiap ulangan terdiri dari 5 ekor DOC sebagai unit percobaan. Perlakuan terdiri dari kontrol negatif, 2,5 $\%$ minyak buah merah, 2,5\% fitobiotik nanoenkapsulasi minyak buah merah, $5 \%$ fitobiotik nanoenkapsulasi minyak buah merah, dan $10 \%$ fitobiotik nanoenkapsulasi minyak buah merah. Hasil penelitian menunjukkan bahwa pemberian fitobiotik nanoenkapsulasi minyak buah merah tidak perpengaruh nyata $(\mathrm{P}>0,05)$ terhadap persentase karkas. Sedangkan hasil analisis data terhadap meat bone ratio berpengaruh nyata $(\mathrm{P}<0,05)$. Hasil uji lanjut DMRT menunjukkan bahwa P2 (2,5\% fitobiotik nanoenkapsulasi minyak buah merah) berbeda nyata $(\mathrm{P}<, 0,05)$ dengan $\mathrm{P} 1$ (2,5\% minyak buah merah), P3 (5\% fitobiotik nanoenkapsulasi minyak buah merah), P4 (10\% fitobiotik nanoenkapsulasi minyak buah merah) tetapi tidak berbeda nyata $(\mathrm{P}>0,05)$ dengan $\mathrm{P} 0$ (tanpa perlakuan fitobiotik nanoenkapsulasi minyak buah merah). Perlakuan terbaik dengan rataan meat bone ratio tertinggi yaitu $\mathrm{P} 2$ dengan pemberian fitobiotik nanoenkapsulasi minyak buah merah $2,5 \%$.
\end{abstract}

Kata kunci: Buah merah, Fitobiotik, Karkas, Meat bone ratio, Nanoenkapsulasi.

\begin{abstract}
This study aims to determine the effect of phytobioch from red fruit oil on the percentage of carcasses and meat bone ratio of native chicken. This study used one way anova single factor. A total of native day old chikens (DOC) were randomly allocated to 5 treatments (4 replication each) and reared in pens 5 DOC each as atrial unit. The treatment consisted of negative control, $2,5 \%$ phytobiotic nanoenkapsulation red fruit oil, $5 \%$ phytobiotic nanoencapsulation of red fruit oil, $10 \%$ phytobiotic nanoencapsulation of red fruit oil. In the water intake. The results showed that the addition of phytobiotic nanoencapsulation of red fruit oil in the water intake did not have a significant effect $(\mathrm{P}>0,05)$ in the percentage of carcasses, but have signicant effect $(\mathrm{P}<0,05)$ in the meat bone ratio. DMRT follow-up test results showed that P2 $(2.5 \%$ phytobiotic nanoencapsulation of red fruit oil) was significantly different $(\mathrm{P}<, 0.05)$ with $\mathrm{P} 1(2.5 \%$ red fruit oil), P3 (5\% fitobiotic nanoencapsulation of red fruit oil), P4 (10\% phytobiotic nanoencapsulation of red fruit oil) but not significantly different $(\mathrm{P}>0.05)$ with $\mathrm{P} 0$ (without phytobiotic treatment of red fruit oil nanoencapsulation). The best treatment with the highest average meat bone ratio was P2 by giving phytobiotic nanoencapsulation of red fruit oil $2.5 \%$.
\end{abstract}

Keywords: Red fruit, Phytobiotic, Carcass, Meat bone ratio, Nanoencapsulation. 
Prosiding Seminar Nasional Pembangunan dan Pendidikan Vokasi Pertanian

Politeknik Pembangunan Pertanian Manokwari, 14 November 2020

e ISSN : 2774-1982

\section{PENDAHULUAN}

Antibiotik merupakan salah satu jenis feed additive yang digunakan dalam campuran pakan atau air minum. Tujuan penggunaannya untuk meningkatkan produktivitas, kesehatan, dan keadaan gizi ternak (Hasrullah, 2017). Penggunaan antibiotik yang tidak terkontrol secara terus menerus sebagai AGP (antibiotic growth promoters) untuk memacu pertumbuhan ayam menyebabkan antibiotik tidak lagi mempan sebagai obat terapi pada hewan ternak. Penggunaan antibiotik juga dapat meninggalkan residu sehingga berbahaya bagi kesehatan, seperti halnya Peraturan Mentri Pertanian (PERMENTAN) nomor 14/PERMENTAN/PK.350/5/2017 yang menerangkan bahwa Pemerintah Indonesia melarang penggunaan antibiotik sebagai pemacu pertumbuhan (Antibiotic Growth Promoters/AGP) pada pakan ternak. Upaya yang dapat dilakukan untuk menanggulangi masalah tersebut adalah mengganti antibiotik dengan tanaman herbal yang memiliki kandungan senyawa-senyawa aktif didalamnya atau disebut fitobiotik yang terbukti tidak meninggalkan residu bagi konsumen.

Fitobiotik adalah adiktif ransum yang berasal dari bahan tanaman herbal (Zuprizal dalam Kusumasari, 2012). Fitobiotik mengandung zat bioaktif sehingga jika digunakan sabagai natural growth promotors pengganti antibiotik dapat berfungsi sebagai zat antibakteri (Putra, 2018). Salah satu tanaman yang berpotensi di Papua dan dapat dimanfaatkan sebagai fitobiotik adalah buah merah.

Buah merah (Pandanus conoideus) adalah buah yang banyak tumbuh di wilayah Papua yang dimanfaatkan oleh masyarakat sebagai obat tradisional. Zat aktif yang terkandung dalam buah merah diantaranya tokoferol (Vitamin E), alfatokoverol dan betakaroten berfungsi sebagai antioksidan yang mampu menangkal radikal bebas dan meningkatkan kekebalan tubuh (Budi and Paimin, 2005). Kandungan zat aktif yang terdapat pada buah merah cukup beragam dan cukup tinggi sehingga diharapkan mampu meningkatkan performa dan kesehatan ayam kampung super. Pemanfaatan minyak buah merah dalam pangan masih sangat terbatas karna sifatnya kurang larut dalam air sehingga untuk meningkatkan pemanfaatannya dibuat dengan teknologi nanoenkapsulasi.

Nanoenkapsulasi merupakan salah satu cara untuk mempertahankan kestabilan suatu senyawa melalui proses pelarutan dalam bentuk nano partikel (Mohanraj and Chen, 2006). Kitosan sebagai salah satu bahan pelarut dalam proses nanoenkapsulasi bersifat tidak beracun, aman dalam produk pangan, serta mudah untuk di preparasi menjadi bentuk nanopartikel (Parize et al,. dalam Ferdiansyah et al., 2017). Teknologi nanoenkapsulasi dapat dilakukan melalui galasi ionik menggunakan kitosan dan sodium 
Prosiding Seminar Nasional Pembangunan dan Pendidikan Vokasi Pertanian

Politeknik Pembangunan Pertanian Manokwari, 14 November 2020

e ISSN : 2774-1982

tripolyphosphate (STPP) yang membentu lapisan pelindung, kemudian direduksi ukuran partikelnya membentuk nano kitosan (Alfandi, 2014). Pemanfaatan minyak buah merah sebagai bahan fitobiotik dengan teknologi nanoenkapsulasi ini diharapkan dapat meningkatkan performa serta kesehatan ayam kampung super, terutama pada persentase karkas dan meat bone ratio.

\section{METODE}

\section{Waktu dan Tempat}

Kegiatan penelitian dilaksanakan di kampus Politeknik Pembangunan Pertanian (Polbangtan) Manokwari selama 3 bulan terhitung dari bulan Maret sampai Mei 2020.

\section{Alat dan Bahan}

Alat penelitian yang digunakan meliput: blender, timbangan digital, hygrometer, pisau daging, kompor, lampu, tirai plastik, ember, tempat pakan, tempat minum, gelas ukur, label, kandang, alat tulis, folder dan kamera.

Bahan penelitian yang digunakan meliputi: minyak buah merah, kitosan, Sodium Tripolyhosphate (STPP), asam asetat, 100 ekor DOC (Day old chick) ayam kampung super lokal yang diperoleh dari peternak yang bernama Bangun, kemudian pakan yang diberikan yaitu pakan broiler starter dari PT. East Hope.

\section{Pembuatan Nanoenkapsulasi}

Proses nanoenkapsulasi menggunakan metode gelasi ionik dengan mencampurkan 0,625\% kitosan (kitosan yang telah dilarutkan dalam 2,50\% asam asetat, diaduk dengan menggunakan blender selama 2 menit) dan 0,75\% STPP (yaitu 0,75\% STPP yang telah dilarutkan dengan aquades dan diaduk menggunakan blender selama 2 menit). Perbandingan larutan nanoenkapsulasi sebagai fitobiotik yaitu minyak buah merah : kitosan dan STPP (0,81:0,16:0,03) (Sundari, 2014; Syaefullah et al., 2019; Timur et al., 2020).

\section{Proedur kerja}

Fitobiotik nanoenkapsulasi minyak buah merah diaplikasikan pada saat pagi hari, kemudian pada sore hari ayam hanya diberikan air minum tanpa fitobiotik nanoenkapsulasi minyak buah merah. Pemberian pakan dilakukan 1 (satu) kali dalam sehari yaitu pada sore hari. Suhu dan kelembaban kandang dicatat 3 (tiga) kali sehari yaitu pagi, siang dan sore. Sedangkan penimbangan bobot badan dilakukan setiap 7 (tujuh) hari sekali. 
Prosiding Seminar Nasional Pembangunan dan Pendidikan Vokasi Pertanian

Politeknik Pembangunan Pertanian Manokwari, 14 November 2020

e ISSN : 2774-1982

\section{Rancangan Penelitian}

Rancangan Penelitian yang digunakan dalam penelitian ini adalah percobaan dengan menggunakan Rancangan Acak Lengkap (RAL) yang terdiri dari 5 perlakuan dan 4 ulangan, masing-masing ulangan terdiri dari 5 ekor ayam. perlakuan yang diberikan adalah sebagai berikut:

$\mathrm{P} 0$ = air minum tanpa adiktif (kontrol);

$\mathrm{P} 1$ = air minum $+2,5 \%$ ekstrak minyak buah merah;

$\mathrm{P} 2$ = air minum $+2,5 \%$ nanoenkapsulasi bioaktif minyak buahmerah;

$\mathrm{P} 3$ = air minum $+5 \%$ nanoenkapsulasi bioaktif minyak buah merah;

P4 = air minum $+10 \%$ nanoenkapsulasi bioaktif minyak buah merah.

\section{Variabel dan Pengukuran}

Variabel yang diukur dalam penelitian ini adalah:

Persentase Karkas

Presentase karkas diperoleh dari hasil perbandingan antara berat karkas (gram) dengan berat hidup (gram) dikali 100\% (Mustaqin dalam Tahalele et al., 2018).

Persentase Karkas $=\frac{\text { Berat karkas }}{\text { Berat hidup }} \times 100 \%$

\section{Meat Bone Ratio}

Untuk menghitung meat bone ratio (perbandingan tulang dan daging) dilakukan setelah mendapat bobot tulang dan bobot daging secara keseluruhan. Dengan data bobot yang telah diperolah maka perbandingan antara banyaknya tulang dan daging dapat dihitung dengan rumus (Priwardana, 2018).

Meat bone ratio $=$ Bobot daging

\section{Analisis Data}

Bobot tulang

Analisis data menggunakan Rancangan Acak Lengkap Pola Searah dengan 5 perlakuan dan 4 ulangan menggunakan program analisis data SPSS dan Microsoft Exel, apabila ada perbedaan maka dilanjutkan dengan uji lanjut Duncan Multiple Range Test (DMRT).

\section{HASIL DAN PEMBAHASAN}

\section{Persentase Karkas}

Persentase karkas dihasilkan dari perbandingan bobot karkas dengan bobot hidup kemudian dikalikan seratus persen (Mustaqin dalam Tahalele et al., 2018). Data 
Prosiding Seminar Nasional Pembangunan dan Pendidikan Vokasi Pertanian Politeknik Pembangunan Pertanian Manokwari, 14 November 2020

e ISSN : 2774-1982

persentase karkas ayam kampung super selama 56 hari pada perlakuan pemberian fitobiotk nanoenkapsulasi minyak buah merah dapat dilihat pada Tabel 1.

Tabel 1. Persentase Karkas (\%)

\begin{tabular}{|c|c|c|c|c|c|c|}
\hline \multirow{2}{*}{ Perlakuan } & \multicolumn{4}{|c|}{ Ulangan } & \multirow{2}{*}{ Rataan $^{\text {ns }}$} & \multirow{2}{*}{$\mathrm{Sd}$} \\
\hline & U1 & $\mathrm{U} 2$ & U3 & U4 & & \\
\hline P0 & 55 & 45 & 57 & 57 & 53,5 & $\pm 5,74$ \\
\hline $\mathrm{P} 1$ & 57 & 54 & 51 & 58 & 55 & $\pm 3,16$ \\
\hline P2 & 55 & 66 & 56 & 58 & 59 & $\pm 4,99$ \\
\hline P3 & 59 & 60 & 74 & 56 & 62,25 & $\pm 8,02$ \\
\hline P4 & 57 & 47 & 54 & 63 & 55,25 & $\pm 6,65$ \\
\hline
\end{tabular}

Keterangan : Nonsignifikan (NS)

Hasil analisis data menunjukkkan bahwa rataan persentase karkas ternak ayam kampung super antar perlakuan P0, P1, P2, P3, dan P4 hasilnya tidak berpengaruh nyata $(\mathrm{P}>0,05)$. Walaupun tidak terjadi perpengaruh nyata namun persentase karkas tertinggi berturut turut P3 (62,25\%), P2 (59\%), P4 (55,25\%) dan P1 (55\%) jika dibanding pemberian minum tanpa perlakuan fitobiotik nanoenkapsulasi minyak buah merah $\mathrm{P} 0$ $(53,5 \%)$.

Hasil penelitian Muniraet al., (2016) menunjukkan persentase karkas ayam kampung super umur 10 minggu yaitu $(54,9-56,4 \%)$. Sedangkan hasil penelitian ini menunjukkan bahwa persentase ayam kampung super umur 8 minggu yaitu (53,5 $62,25 \%)$. Hasil ini ternyata tidak jauh berbeda.

Berdasarkan hasi penelitian menunjukan bahwa presentase karkas pada P3 (5 \% fitobiotik nanoenakpsulasi minyak buah merah) lebih baik dari pada P0 (Kontrol). Hal ini terjadi karenaasam lemak yang terdapat dalam minyak buah merah sangat penting dalam proses sintensis dan metabolisme tubuh. Kandungan lemak yang semakin meningkat dapat mempengaruhi berat dan persentase karkas yang dihasilkan (Ollonget al., 2012). Salah satu senyawa aktif yang terkandung dalam minyak buah merah yaitu tokoferol. Tokoferol berperan penting dalam penyerapan nutrisi dalam usus halus menjadi lebih baik (McClements et al., 2016)

Dari hasil penelitian ini ternyata penambahan fitobiotik minyak buah merah dalam jumlah kecil 2,5\% belum mampu meningkatkan persentase karkas ayam kampung super. Sama halnya dengan hasil penelitian Ollong et al., (2012) bahwa penambahan minyak buah merah dalam jumlah 2- $4 \%$ belum bisa meningkatkan persentase karkas.Sedangkan pemberian $10 \%$ minyak buah merah menghasilkan persentase karkas yang rendah dibanding 5\%. Sesuai dengan pernyataan Zuidhof et al., (2009), bahwa penambahan 
Prosiding Seminar Nasional Pembangunan dan Pendidikan Vokasi Pertanian

Politeknik Pembangunan Pertanian Manokwari, 14 November 2020

e ISSN : 2774-1982

minyak pada persentase yang lebih tinggi dapat menurunkan berat karkas. Hal ini disebabkan karena kebutuhan nutrisi di setiap fase pertumbuhan tidak sama, sehingga menyebabkan tidak seimbangnya komposisi energi, lemak, asam amino, serat kasar, vitamin dan mineral (Ollong et al.,2012). Sementara itu faktor-faktor yang pengaruhi persentase karkas diantaranya, umur, jenis kelamin, bobot potong besar dan konformasi tubuh, perlemakan, kualitas dan kuantitas ransum serta strain yang dipelihara (Husna, 2016).

\section{Meat Bone Ratio}

Meat bone ratio didapatkan dari hasil perbandingan bobot daging dan bobot tulang (Priwardana, 2018). Hasil rataan meat bone ratio ayam kampung super selama 56 hari pada perlakuan pemberian fitobiotk nanoenkapsulasi minyak buah merah dapat dilihat pada Tabel 2 dibawah ini.

Tabel 2. Rata-rata Meat Bone Ratio Ayam Kampung Super

\begin{tabular}{ccccccc}
\hline \multirow{2}{*}{ Pelakuan } & \multicolumn{5}{c}{ Ulangan } & \multicolumn{2}{c}{ Rataan } & Sd \\
\cline { 2 - 5 } & $\mathrm{U} 1$ & $\mathrm{U} 2$ & $\mathrm{U} 3$ & $\mathrm{U} 4$ & $1,93^{\mathrm{c}}$ & $\pm 0,06$ \\
$\mathrm{P} 0$ & 1,96 & 1,95 & 1,83 & 1,99 & $1,45^{\mathrm{a}}$ & $\pm 0,13$ \\
$\mathrm{P} 1$ & 1,40 & 1,39 & 1,34 & 1,68 & $1,97^{\mathrm{c}}$ & $\pm 0,04$ \\
P2 & 1,93 & 2 & 2,01 & 1,92 & $1,69^{\mathrm{b}}$ & $\pm 0,19$ \\
P3 & 1,95 & 1,42 & 1,70 & 1,69 & $1,72^{\mathrm{b}}$ & $\pm 0,04$ \\
\hline
\end{tabular}

Keterangan : Superskrip yang berbeda menunjukkan perbedaan yang nyata

Hasil analisis data menunjukkkan bahwa pemberian Fitobiotik nanoenkapsulasi minyak buah merah berpengaruh nyata $(\mathrm{P}<0,05)$ terhadap meat bone ratio ayam kampung super. Hasil analisis data terkait rataan meat bone ratio dapat dilihat pada lampiran 3 . Hal tersebut diduga karena adanya penambahan minyak buah merah. Minyak atau lipida sangat penting peranannya dalam pertumbuhan ayam, dalam hal ini sebagai sumber energi, membantu absorpsi vitamin yang larut dalam lemak, membantu palabilitas makanan dan juga berfungsi sebagai sumber panas (Fadilah et al., 2007).

Hasil uji lanjut Duncan Multiple Range Test (DMRT) menunjukkan bahwa P2 (2,5\% fitobiotik nanoenkapsulasi minyak buah merah) berbeda nyata $(\mathrm{P}<, 0,05)$ dengan P1 (2,5\% minyak buah merah), P3 (5\% fitobiotik nanoenkapsulasi minyak buah merah), P4 (10\% fitobiotik nanoenkapsulasi minyak buah merah) tetapi tidak berbeda nyata $(\mathrm{P}>0,05)$ dengan $\mathrm{P0}$ (tanpa perlakuan fitobiotik nanoenkapsulasi minyak buah merah). 
Prosiding Seminar Nasional Pembangunan dan Pendidikan Vokasi Pertanian Politeknik Pembangunan Pertanian Manokwari, 14 November 2020

e ISSN : 2774-1982

Perlakuan terbaik dengan rataan meat bone ratio tertinggi yaitu pada P2 dengan pemberian fitobiotik nanoenkapsulasi minyak buah merah 2,5\%. Hal ini menunjukkan bahwa penambahan fitobiotik minyak buah merah mempengaruhi meat bone ratio. Hasil ini lebih tinggi jika dibandingkan hasil penelitian Samsudin et al,. (2012) yaitu 1,12 1,26 karena pemberian sari buah merah mampu menekan pembentukan lemak pada ayam, tetapi lebih mendorong pembentukan daging. Perbandingan daging dan tulang dipengaruhi oleh karkas, tingginya bobot daging akan berpengaruh pada perbandingan daging dan tulang, semakin tinggi nilai perbandingan daging dan tulang pada karkas maka bagian yang dikonsumsi semakin tinggi dan berpengaruh pada kualitas karkas yang tinggi pula. Daging merupakan bagian terbesar dari karkas yaitu berkisar 54\%, dengan kisaran persentase tulang bervariasi antara 17-25\% (Budi and Paimin, 2005; Samsudin et al,. 2012; Singarimbun 2013; Summers 2004).

\section{KESIMPULAN DAN SARAN}

Berdasarkan hasil penelitian dapat disimpulkan bahwa penambahan fitobiotik nanoenkapsulasi minyak buah merah tidak berpengaruh nyata terhadap persentase karkas akan tetapi pemberian fitobiotik nanoenkapsulasi minyak buah merah berpengaruh nyata terhadap meat bone ratio.

Dari hasil penelitian ini dapat disarankan penelitian lebih lanjut terkait fitobiotik nanoenkapsulasi minyak buah merah pada unggas lainnya seperti itik, ayak petelur, ayam broiler dan lain-lain.

\section{UCAPAN TERIMA KASIH}

Terimakasih kepada kedua dosen pembimbing serta dosen Polbangtan Manokwari yang telah membantu dalam proses penelitian dan penulisan laporan..

\section{DAFTAR PUSTAKA}

Alfandi, F.A. (2014). Pengaruh Nanoenkapsulasi Terhadap Mutu Sensori, Fisikokimia, dan Fisiologiaktif Minuman Fungsional Berbasis Kumis Kucing (Orthosiphon aristatus Bl. Miq). Tesis. Fakultas Teknologi Pertanian. Institut Pertanian Bogor. Bogor, Indonesia.

Budi, I. \& Paimin, P. R. (2005). Buah Merah. Jakarta : Penebar Swadaya.

Fadilah, R., Polama, A., Alam, S., \& Paewanto, E. (2007). Sukses Beternak Ayam Broiler. PT Agromedia Pustaka. Jakarta.

Ferdiansyah, F., Heriyanto, H., Wijaya. C.H., \& Limantara. L. (2017). Pengaruh Metode Nanoenkapsulasi Terhadap Stabilitas Pigmen Karotenoid dan Umur Simpan 
Prosiding Seminar Nasional Pembangunan dan Pendidikan Vokasi Pertanian

Politeknik Pembangunan Pertanian Manokwari, 14 November 2020

e ISSN : 2774-1982

Minyak Dari Buah Merah (Pandanus conoideus L). Jurnal Universitas Pembangunan Jaya. 37(4):369-376.

Hasrullah. (2017). Status Hematologis Broiler dengan Penambahan Fitobiotik Ekstrak Kunyit dan Bawang Putih degan Infeksi Bakteri Salmonella sp. Skripsi. Universitas Hasanuddin Makassar.

Husna, N.V., Setiawan, I., \& Sujana. E. (2016). Bobot Potong Bobot Bagian Edible dan In Edible Ayam Hasil Persilangan Pejantan Bangkok dengan Betiana Ras Petelur. Jurnal Universitas Pajajaran. 1-10.

Kusumasari Y.F.Y., Yunianto V.D \& Suprijatna E. (2012). Pemberian Fitobiotik yang Berasal dari Mahkota Dewa (Phaleria macrocarpa) terhadap Kadar Hemoglobin dan Hematokrit pada Ayam Broiler. Jurnal. Universitas Diponegoro.1(4):129-132.

McClements, D.J., Saliva-Trujillo, L., Zhang, R., Zhang, Z., Zou, L., Yao, M., \& Xiao, H. (2016). Boosting the bioavailability of hydrophobic nutrients, vitamins, and nutraceuticals in natural products using excipient emulsions. Food Research international 88, 140-152.

Mohanraj,V.J., \& Chen, Y. (2006). Nanoparticles-a review. Tropical Journal of Phamaceutical Research. 5(1):561-573.

Munira, S., Nafiu, L.O., \& Tesse, A.M. (2016). Performans Ayam Kmpung Super pada Pakan yang Disubtitusi Dedak Padi Fermentasi dengan Fermentor berbeda. Jurnal Fakultas Peternakan UHO. 3(2):22-29.

Ollong, A.R., Wihandoyo \& Erwanto Y. (2012). Pengaruh Pemberian Minyak Buah Merah (Pandanus conoideus Lam) Terhadap Bobot Badan akhir, Karkas dan Hati Ayam Broiler. Jurnal. Universitas Negri Papua. Manokwari Papua Barat.

Putra. D.R. (2018). Pemberian Fitobiotik Ekstrak Kunyit dan Bawang Putih Terhadap Tingkat Kerusakan Organ Hati dan Usus Halus Broiler yang Diinfeksi. Skripsi. Universitas Hasanuddin Makassar.

Priwardana, F.O. (2018). Pengaruh Bangsa dan Umur Potong Terhadap Presentase Karkas dan Meat Bone Ratio Sapi Potong. Jurnal. Universitas Mercu muana. Yokyakarta.

Summers, J.D. (2004). Broiler Carcass Composition. Poultry Industry Council for Research and Education. Guelph.

Samsudin, M., Sarengat W., \& Maulana H.N. (2012). Pengaruh Perbedaan Lama Periode (Starter-Finisher) Pemberian Pakan dan Level Protein terhadap Nisbah Daging Tulang dan Massa Protein Daging Dada dan Paha Ayam Pelung Umur 1 Minggu sampai 11 Minggu. Animal Agricultural Journal, 1(1):43-51.

Sundari, Zuprizal \& Martien, R. (2014). The Effect Nanocapsule of Turmeric Extracts in Rations on Nutrient Digestibility of Broiler Chickens. Animal Production.16:107113.

Syaefullah, B. L., Herawati, M., Timur, N. P. V. T., Bachtiar, E. E., \& Maulana, F. (2019). INCOME OVER FEED COST PADA AYAM KAMPUNG YANG DIBERI NANOENKAPSULASI MINYAK BUAH MERAH (Pandanus conoideus) VIA WATER INTAKE. Jurnal Triton, 10(2), 54-61. 
Prosiding Seminar Nasional Pembangunan dan Pendidikan Vokasi Pertanian

Politeknik Pembangunan Pertanian Manokwari, 14 November 2020

e ISSN : 2774-1982

Timur, V., Herawati, M., Syaefullah, B. L., \& Bachtiar, E. (2020). Mortalitas dan Profil Organ Dalam Ayam Kampung yang diberi Fitobiotik Nanoenkapsulasi Minyak Buah Merah (Pandanus conoideus). Jurnal Triton, 11(1), 16-23.

Tahalele Y., Mortong M.E.R., Nangoy F.J., \& Sarajar C.L.K. (2018). Pengaruh Penambahan Ramuan Herbal Pada Air Minum Terhadap Presentase Karkas, Presentase Lemak Abdomen dan Presentase Hati Pada Ayam Kampung Super. JurnalUniversitas Sam Ratulangi Manado. 38(1):160:168. 